Jahangirnagar University J. Biol. Sci. 3(2): 73-80, 2014 (December)

\title{
Effect of different management tactics on the incidence and movement of red pumpkin beetle, Aulacophora foveicollis on the leaves of sweet gourd, Cucurbita moschata
}

\author{
M. M. H. Khan \\ Department of Entomology, Patuakhali Science and Technology University \\ Dumki, Patuakhali, Bangladesh
}

\begin{abstract}
Incidence and movement of red pumpkin beetle (RPB), Aulacophora foveicollis on the leaves of sweet gourd, Cucurbita moschata were examined against different management tactics. Result revealed that no significant difference was observed on the number of red pumpkin beetle on young leaf among the plots treated with different management tactics. Mature leaf support more number of RPB compared to that of young leaf and the population of RPB gradually increased from $1^{\text {st }}$ to $3^{\text {rd }}$ week. The mean number of RPB per plant was higher on upper leaf surface as compared to lower leaf surface in all the treated plots during early hours of the day before $10 \mathrm{am}$. The highest number of RPB was observed at 7:00 am on the upper surface and at 1:00 pm on the lower surface of leaves. The percent reduction of RPB over control on both surfaces of leaf was maximum $(100 \%)$ by the use of mosquito net barrier $\left(\mathrm{T}_{3}\right)$ treated plot at 7:00 and 10:00 am, respectively compared to control. The percent reduction of RPB over control at 1:00 pm ranged $94 \%$ to $98 \%$ on upper leaf surface and at 4:00 pm ranged $94 \%$ to $96 \%$ on lower surface in $\mathrm{T}_{3}$ treated plot. The minimum acceptable level of percent reduction (above 87\%) of RPB population over control was achieved by application of forwatap 4G @ 4g/plant, Nitro 505 EC @ 1 ml/L, hand picking of adult RPB and planting of musk melon as trap crop. The movement of the adult RPB as expressed through the distribution of the beetles on the upper and lower leaf surfaces of sweet gourd during different hours of a day could be helpful for devising the mechanical and chemical control strategies.
\end{abstract}

Key words: Management tactics, incidence, movement, red pumpkib beetle, sweet gourd leaves

\section{INTRODUCTION}

Sweet gourd (Cucurbita moschata Duch.ex Poir) locally known as 'misty kumra' or 'misty lau' or 'misty kadu', is one of the most important vegetable crop grown in Bangladesh. It is relatively high in energy and carbohydrate content and a good source of vitamins, especially high carotenoid pigments and minerals (Bose \& Som 1998). The delicate shoots and leaves of sweet gourd are preferred by the people for its use as delicious vegetables. The fleshy fruits can be consumed at immature and mature stages and ripe fruits can be stored for 2 to 4 months (Yawalkar, 1985). From the economic point of view, these vegetables play an important role for its reasonable market price, ability to grow throughout the year and availability during the lean period of vegetables supply in the country.

Sweet gourd plants are attacked by several insect pests of which red pumpkin beetle, Aulacophora foveicollis is the most destructive pest in Bangladesh (Anon, 1995) and is responsible for considerable damage in India (Butani \& Jotwani 1984). Its damage 
potential is one of the important constraints of sweet gourd production. Considering the seriousness of this pest a wide range of organophosphorus, carbamate and synthetic pyrethroids of various formulations have been used from time to time against this pest (Alam, 1969; Chattopadhyay, 1991; Krishnaiah et al., 1979; Singh et al., 1984; Borah, 1997). The indiscriminate and non-judicious use of insecticides may result in a series of problems related to both loss of their effectiveness in the long run and certain externalities such as pollution and health hazards (FAO, 2003). Various non-chemical approaches like clean cultivation, field sanitation, early sowing of vine crops, rotation of crops, examination of young plants soon after germination, collection of beetles, dusting of ashes, ploughing up the fields after harvest, covering plants with net, are helpful approaches for managing red pumpkin beetle (Austin, 1925; Hazarika, 1951; Azim, 1966; Butani \& Jotwani, 1984; Yawalkar, 1985; Nair, 1986; Chauhan, 1989; Chattopadhyay, 1991). Mosquito net barrier at seedling stage up to $1 \frac{1 / 2}{2}$ month was most effective treatment for the control of red pumpkin beetle of sweet gourd during Rabi season (Anon, 2007).

The review reveals that among the available pest control measures, chemical insecticides are still vital and provide a cost effective pest control tool to the farmer. Due to lack of knowledge and availability of non-chemical pest management approaches and their integration, growers of this country mostly depend on insecticide to keep the crop production steady. Reports indicate that among organophosphorus, carbamate and synthetic pyrethroids, Malathion, Diazinon, carbaryl, carbofuran, chlorpyriphos, cypermethrin are frequently used against red pumpkin beetle. Cypermethrin, a synthetic pyrethroid are popularly used for its quick knock down action with the quality of nonphytotoxic and almost non-toxic effect to mammals (Reddy \& Joshi, 1992). To avoid total reliance on chemicals, its alternate approaches are needed. There are many effective non-chemical components available in the country which may be exploited side by side with the chemical components. Thus, the present study was attempted to evaluate the effectiveness of some non-chemical and chemical approaches on the incidence and movement of red pumpkin beetle on the upper and lower leaf surface of sweet gourd plants were studied.

\section{MATERIALS AND METHODS}

Field experiment was conducted at experimental farm of BSMRAU, Gazipur during March to June, 2008 to evaluate the effectiveness of different management tactics on the incidence and behavioural biology of red pumpkin beetle. A year round local variety of sweet gourd was included in the study. Nine management tactics were tested with an untreated control. Management tactics were: $T_{1}=$ planting of musk melon as trap crop, $T_{2}$ $=$ hand picking of adult RPB, $\mathrm{T}_{3}=$ use of mosquito net barrier for 4 weeks, $\mathrm{T}_{4}=$ Forwatap $4 \mathrm{G} @ 4 \mathrm{~g} /$ plant , $\mathrm{T}_{5}=$ Forwatap $4 \mathrm{G} @ 3 \mathrm{~g} /$ plant, $\mathrm{T}_{6}=$ Emithion $50 \mathrm{EC} @ 2 \mathrm{ml} / 1 \mathrm{of}$ water, $\mathrm{T}_{7}=$ Morter $48 \mathrm{EC} @ 1 \mathrm{ml} / 1$ of water, $\mathrm{T}_{8}=$ Vitabryl $85 \mathrm{WP} @ 34.4 \mathrm{~g} / 1$ of water, $\mathrm{T}_{9}=$ Nitro $505 \mathrm{EC} @ 1 \mathrm{ml} / \mathrm{l}$ of water and $\mathrm{T}_{10}=$ untreated control (only water spray). The experiment was laid out in randomized complete block design (RCBD) with three replications. The total area of the experimental plot was $700 \mathrm{~m}^{2}$ and the whole plot was 
divided into 30 equal sub-plots to accommodate 3 replications having 10 sub-plots with 20 plants per replication. Therefore, there were 60 plants in the whole experiment. The size of the sub-plot was $4 \mathrm{~m} \times 3 \mathrm{~m}$ with an inter plot distance of $1 \mathrm{~m}$ and row to row distance $2 \mathrm{~m}$. Two pits of $30 \mathrm{~cm} \times 30 \mathrm{~cm} \times 20 \mathrm{~cm}$ size were dug at one side of each plot at a distance of $2 \mathrm{~m}$ between pits to facilitate well spreading of cucurbit vines and also for easy inspection and data recording.

All insecticides were applied at 3 days after transplanting (DAT) for establishment of seedlings in field and subsequent spraying or application was done at 7 days interval in case of foliar insecticides with knapsack sprayer and at 10 days interval in case of granular insecticide. The foliar insecticide was applied on upper and lower surfaces of the leaves to ensure complete coverage of the plants. The spray was always done in the afternoon to avoid scorching sun, insecticidal drift and protecting pollinating wild bees and other beneficial insects. The granular insecticides were applied into the moist soil around each plant. Untreated control plants were sprayed with tap water in the same manner. During the application of insecticides, precautions were taken to avoid drift to the adjacent plots by using polythene sheet between plots.

Fertilizer Application : Cow dung and fertilizer were applied as recommended by Rashid (1993) for cucurbits at the rate of 10,000, 69, 60 and $60 \mathrm{~kg}$ of cow dung, N, P and $\mathrm{K}$ per ha, respectively. The half of cow dung, TSP and MP and one third of urea were applied as basal dose during land preparation. The remaining cow dung, TSP and MP were applied in the pit 15 days before transplanting of seedlings. The rest of urea was applied as top dressing after each flush of flowering and fruiting in three equal splits.

Raising and Transplanting of Seedlings: The seeds of a year round local variety of sweet gourd were procured from Siddique Bazar, Dhaka. The seeds of sweet gourd (@ 2 seeds per bag) were sown on 08 March 2008 in polythene bag $(15 \mathrm{~cm} \times 10 \mathrm{~cm})$ containing a mixture of equal proportion of well decomposed cow dung and sandy loam soil and irrigated regularly. After germination, the seedlings were also sprayed with water by a hand sprayer. After 1 week, the seedlings were transferred to a sunny place for hardening. Two seedlings of 15 days old were transplanted on 30 March 2008 in each of the two pits of the experimental plots $(4 \mathrm{~m} \times 3 \mathrm{~m})$. One healthy seedling was kept in each pit after establishment of seedlings in the field.

Intercultural operation: After transplanting of seedling, a light irrigation was applied. Subsequent irrigation was applied in all plots as and when needed. After 7 days of transplanting, single healthy seedling with luxuriant growth per pit was allowed to grow. Other recommended agronomic practices were followed as suggested by Rashid (1993) from time to time to raise a healthy crop.

Collection of Data: To evaluate the effect of non-chemical approaches and chemical insecticides for suppressing red pumpkin beetle, data on the number of beetle per leaf per day on $1^{\text {st }}, 2^{\text {nd }}$ and $3^{\text {rd }}$ weeks was recorded. The behavioural biology of the adult RPB particularly their movement on upper and lower leaf surfaces during different hours of the 
day as affected by management tactics was studied. The mean number of beetles recorded during 6 observational days from 14 to 49 days after transplanting (DAT) and percent reduction over control on the upper and lower surfaces of leaves per plant at 7:00 AM, 10:00 AM, 1:00 PM and 4:00 PM of the day in all treated plots were calculated.

Data Analysis: All the data of this study were analyzed by using MSTAT-C software. The percentage data were transformed through Square root transformation as and when needed. Means were separated by Duncan's Multiple Range Test (DMRT).

\section{RESULTS AND DISCUSSION}

Effect of different management tactics on suppressing red pumpkin beetle (RPB): The comparative effectiveness of different management tactics on the number of red pumpkin beetle per day on young and mature leaves of sweet gourd in three separate weeks after application have been presented in Table 1. At mature leaf stage, no red pumpkin beetle $(0.00)$ was recorded in $\mathrm{T}_{3}$ treated plots (use of mosquito net barrier) which was statistically similar to those of $\mathrm{T}_{9}$ treated plots (Nitro $505 \mathrm{EC} @ 1 \mathrm{ml} / \mathrm{l}$ water at 7 days interval) (0.33) and $\mathrm{T}_{4}$ (Forwatap $4 \mathrm{G} @ 4 \mathrm{~g} / \mathrm{plant}$ ) (0.37) followed by $\mathrm{T}_{1}$ (planting of musk melon as trap crop) (1.00) and $\mathrm{T}_{2}$ (hand picking of adult RPB) (1.00). There was no significant difference observed on the mean number of red pumpkin beetles among the plots treated with $\mathrm{T}_{5}$ (Forwatap $4 \mathrm{G} @ 3 \mathrm{~g} / \mathrm{plant}$ ), $\mathrm{T}_{6}$ (Emithion $50 \mathrm{EC} @ 2 \mathrm{ml} / \mathrm{l}$ water), $\mathrm{T}_{7}$ (Morter 48 EC @ 1 ml/l water) and $\mathrm{T}_{8}$ (Vitabryl 85 WP @ $34.4 \mathrm{~g} / \mathrm{l}$ water). Significantly the highest number (6.00) of red pumpkin beetles was observed in control plots $\left(\mathrm{T}_{10}\right)$. In young leaf, no significant difference was observed on the number of red pumpkin beetle appeared within 01 to 07 April $\left(1^{\text {st }}\right.$ week) among the plots treated with 10 different management tactics.

Similarly, on the second week (within 08 to 14 April), on mature leaf, no red pumpkin beetle was recorded in $T_{3}$ treated plots. The second lowest number was observed in $T_{4}$ plots (0.92) which was statistically similar to those of $\mathrm{T}_{9}(1.00), \mathrm{T}_{1}(1.00)$ and $\mathrm{T}_{2}$ treated plots (1.00) followed by $\mathrm{T}_{8}$ plots. No significant difference was observed on the mean number of red pumpkin beetles among the plots treated with $T_{5}, T_{6}$, and $T_{7}$. Significantly highest number (5.00) of red pumpkin beetles was observed in control $\left(\mathrm{T}_{10}\right)$. At young leaf, no significant difference was observed on the number of red pumpkin beetle appeared within 08 to 14 April ( $2^{\text {nd }}$ week) among the plots treated with 10 different management tactics (Table 1).

On the $3^{\text {rd }}$ week (within 15 to 21 April), in mature leaf of sweet gourd, no red pumpkin beetle was appeared in $T_{3}$ treated plots which was statistically similar to those of $T_{4}$ (0.37), $\mathrm{T}_{9}(0.33), \mathrm{T}_{7}(1.00), \mathrm{T}_{2}(1.50), \mathrm{T}_{1}(1.67)$, and $\mathrm{T}_{5}(2.00)$ treated plants but they were significantly different from other treated plots. Significantly the highest number (9.50) of red pumpkin beetles was observed in control plots $\left(\mathrm{T}_{10}\right)$. In young leaf, no significant difference was observed on the number of red pumpkin beetle among the plots treated with 10 different management tactics (Table 1). It is evident from this table that mature leaf support more number of RPB compared to that of young leaf and the population of RPB gradually increased from $1^{\text {st }}$ to $3^{\text {rd }}$ week. 
Table 1. Effect of management tactics on the incidence of red pumpkin beetle (RPB) after different weeks of their applications on young and mature leaves of sweet gourd

\begin{tabular}{c|c|c|c|c|c|c}
\hline \multirow{2}{*}{ Treatment } & \multicolumn{2}{|c|}{ Mean number of RPB per day on mature and young leaves at different weeks } \\
\cline { 2 - 6 } & \multicolumn{2}{|c|}{$\begin{array}{c}1^{\text {st }} \text { week } \\
(01-07 \text { April) }\end{array}$} & \multicolumn{2}{c|}{$\begin{array}{c}2^{\text {nd }} \text { week } \\
(08-14 \text { April })\end{array}$} & \multicolumn{2}{|c}{$\begin{array}{c}3^{\text {rd }} \text { week } \\
(15-21 \text { April })\end{array}$} \\
\cline { 2 - 7 } & Mature leaf & $\begin{array}{c}\text { Young } \\
\text { leaf }\end{array}$ & Mature leaf & Young leaf & Mature leaf & $\begin{array}{c}\text { Young } \\
\text { leaf }\end{array}$ \\
\hline $\mathrm{T}_{1}$ & $1.00 \mathrm{c}$ & 0.0 & $1.0 \mathrm{c}$ & 0.0 & $1.67 \mathrm{~cd}$ & 0.0 \\
$\mathrm{~T}_{2}$ & $1.00 \mathrm{c}$ & 0.0 & $1.07 \mathrm{c}$ & 0.33 & $1.50 \mathrm{~cd}$ & 0.33 \\
$\mathrm{~T}_{3}$ & $0.00 \mathrm{~d}$ & 0.0 & $0.0 \mathrm{~d}$ & 0.0 & $0.33 \mathrm{~d}$ & 0.0 \\
$\mathrm{~T}_{4}$ & $0.37 \mathrm{~d}$ & 0.0 & $0.92 \mathrm{c}$ & 0.0 & $0.78 \mathrm{~d}$ & 0.33 \\
$\mathrm{~T}_{5}$ & $3.00 \mathrm{~b}$ & 1.0 & $2.33 \mathrm{~b}$ & 0.67 & $2.0 \mathrm{~cd}$ & 0.67 \\
$\mathrm{~T}_{6}$ & $2.00 \mathrm{~b}$ & 0.0 & $3.33 \mathrm{~b}$ & 0.33 & $4.0 \mathrm{~b}$ & 0.67 \\
$\mathrm{~T}_{7}$ & $2.00 \mathrm{~b}$ & 0.0 & $2.33 \mathrm{~b}$ & 0.0 & $1.0 \mathrm{~d}$ & 0.67 \\
$\mathrm{~T}_{8}$ & $1.50 \mathrm{~b}$ & 0.0 & $2.0 \mathrm{bc}$ & 0.0 & $2.67 \mathrm{c}$ & 0.33 \\
$\mathrm{~T}_{9}$ & $0.33 \mathrm{~d}$ & 0.0 & $1.0 \mathrm{c}$ & 0.0 & $0.67 \mathrm{~d}$ & 0.0 \\
$\mathrm{~T}_{10}$ & $6.00 \mathrm{a}$ & 1.5 & $5.0 \mathrm{a}$ & 1.0 & $9.5 \mathrm{a}$ & 1.0 \\
\hline $\mathrm{F}$ value & 2.51 & $\mathrm{NS}$ & 2.49 & $\mathrm{NS}$ & 3.54 & $\mathrm{NS}$ \\
\hline $\mathrm{CV} \%$ & 11.30 & 8.74 & 10.23 & 7.56 & 12.36 & 13.12 \\
\hline
\end{tabular}

In a column, means followed by different letters are significantly different at $5 \%$ level by Duncan's Multiple Range Test (DMRT).

Values are averages of 3 replications.

Figures within parentheses are the transformed values based on Square root transformation $\{\sqrt{ }(x+0.5)\}$.

$\mathrm{T}_{1}=$ planting of musk melon as trap crop, $\mathrm{T}_{2}=$ hand picking of adult RPB, $\mathrm{T}_{3}=$ use of mosquito net barrier, $\mathrm{T}_{4}=$ Forwatap 4G @ $4 \mathrm{~g} /$ plant twice at 10 days interval, $\mathrm{T}_{5}=$ Forwatap 4G@3 g/plant twice at 10 days interval, $\mathrm{T}_{6}=$ Emithion $50 \mathrm{EC} @ 2 \mathrm{ml} / \mathrm{L}$ of water twice at 7 days interval, $\mathrm{T}_{7}=$ Morter $48 \mathrm{EC} @ 1 \mathrm{ml} / \mathrm{L}$ of water twice at 7 days interval, $\mathrm{T}_{8}=$ Vitabryl 85 WP @ $3.34 \mathrm{~g} / \mathrm{L}$ of water twice at 7 days interval, $\mathrm{T}_{9}=$ Nitro $505 \mathrm{EC} @ 1 \mathrm{ml} / \mathrm{L}$ of water twice at 7 days interval and $\mathrm{T}_{10}=$ untreated control.

Effect of management tactics on movement of RPB during different hours of the day: The movement of the adult RPB particularly their movement on upper and lower leaf surfaces during different hours of the day as affected by management tactics and the mean number of beetles recorded during 6 observational days from 14 to 49 DAT and percent reduction over control on the upper and lower surfaces of leaves per plant at 7:00 AM, 10:00 AM, 1:00 PM and 4:00 PM of the day in all treated plots are presented in Table 2.

At 7:00 AM, the mean number of RPB per plant was higher on upper leaf surface than that of the lower leaf surface in all the treated plots. At 10:00 AM, the similar trend of the mean number of adult RPB per plant on upper and lower leaf surfaces in all the treated plots was observed. At 1:00 PM, the mean number of adult RPB per plant was higher on lower leaf surface than that of the upper leaf surface in all the treated plots. At 4:00 PM, the mean number of adult RPB per plant was higher on upper leaf surface than that of the lower leaf surface in all the treated plots (Table 2). Thus, from the findings of this study it 
can be concluded that the general trend of the mean number of adult RPB per plant in all treated plots including the untreated control indicate the higher number of the adult beetles was at 7:00 am on the upper surface and at 1:00 pm on the lower surface of leaves. The behavioural biology of the adult RPB as expressed through the distribution of the beetles on the upper and lower leaf surfaces of a food plant during different hours of a day can be helpful for devising the mechanical and chemical control strategies. The adult RPB are more abundant on the upper leaf surfaces than on the lower leaf surfaces during the early hours of the day before 10:00 am (Table 2).

The polarized light orientation at morning and afternoon hours of the day enables insects to maintain a steady course across open, unfamiliar teritory when sun navigation or orientation by landmarks is not possible (Atkins, 1978). Therefore, the incidence of RPB in sweet gourd was higher during these periods. It was evident that the beetle number decreased with the increase of sunshine and prevailing high temperature during middle of the day. In general, phytophagous insects always avoid scorching sun to protect themselves from desiccation (Atkins, 1978; Chapman, 1978). In this situation, they tried to conceal them under soil, leaves and debris. Bright sunlight with high prevailing temperature is always unfavourable for phytophagous insects including coleoptera (Hill, 1983).

Table 2. Effect of management tactics on the movement of red pumpkin beetles on the upper and lower leaf surfaces of pumpkin plants observed at different hours

\begin{tabular}{c|ccccc|c|c|c|c}
\hline \multirow{2}{*}{ Treatments } & \multicolumn{8}{|c}{ Mean number of adult RPB per plant per day at hours } \\
\cline { 2 - 10 } & \multicolumn{2}{|c}{$7: 00$ am } & \multicolumn{2}{c}{$10: 00$ am } & \multicolumn{2}{c}{$1: 00$ pm } & \multicolumn{2}{c}{$4: 00$ pm } \\
\cline { 2 - 10 } & ULS & LLS & ULS & LLS & ULS & LLS & ULS & LLS \\
\hline $\mathrm{T}_{1}$ & 0.35 & 0.24 & 0.37 & 0.28 & 0.07 & 0.10 & 0.41 & 0.31 \\
& $(93.0)$ & $(88.0)$ & $(93.6)$ & $(87.3)$ & $(90.3)$ & $(92.6)$ & $(90.2)$ & $(73.7)$ \\
$\mathrm{T}_{2}$ & 0.41 & 0.32 & 0.49 & 0.34 & 0.10 & 0.13 & 0.52 & 0.42 \\
& $(91.8)$ & $(84.0)$ & $(91.5)$ & $(85.2)$ & $(86.1)$ & $(90.4)$ & $(87.6)$ & $(64.4)$ \\
$\mathrm{T}_{3}$ & 0.00 & 0.00 & 0.00 & 0.00 & 0.04 & 0.06 & 0.08 & 0.04 \\
& $(100)$ & $(100)$ & $(100)$ & $(100)$ & $(94.4)$ & $(95.6)$ & $(98.1)$ & $(96.6)$ \\
$\mathrm{T}_{4}$ & 0.31 & 0.33 & 0.56 & 0.55 & 0.09 & 0.18 & 0.38 & 0.39 \\
& $(93.8)$ & $(83.5)$ & $(90.2)$ & $(75.1)$ & $(87.5)$ & $(86.7)$ & $(90.9)$ & $(66.9)$ \\
$\mathrm{T}_{5}$ & 2.15 & 0.98 & 2.21 & 1.01 & 0.21 & 0.23 & 1.12 & 0.56 \\
& $(57.0)$ & $(51.0)$ & $(61.5)$ & $(54.3)$ & $(70.8)$ & $(82.9)$ & $(73.3)$ & $(52.5)$ \\
$\mathrm{T}_{6}$ & 3.12 & 1.04 & 3.15 & 1.11 & 0.23 & 0.27 & 1.76 & 0.63 \\
& $(37.6)$ & $(48.0)$ & $(45.1)$ & $(49.8)$ & $(68.1)$ & $(80.0)$ & $(58.1)$ & $(46.6)$ \\
$\mathrm{T}_{7}$ & 2.00 & 0.87 & 2.12 & 0.92 & 0.29 & 0.33 & 1.10 & 0.45 \\
& $(46.0)$ & $(56.5)$ & $(63.1)$ & $(58.4)$ & $(59.7)$ & $(75.6)$ & $(73.8)$ & $(61.8)$ \\
$\mathrm{T}_{8}$ & 1.38 & 0.68 & 1.39 & 0.71 & 0.19 & 0.26 & 1.31 & 0.48 \\
& $(72.4)$ & $(66.0)$ & $(75.8)$ & $(67.9)$ & $(73.6)$ & $(80.7)$ & $(68.8)$ & $(59.3)$ \\
$\mathrm{T}_{9}$ & 0.28 & 0.32 & 0.57 & 0.46 & 0.08 & 0.09 & 0.46 & 0.14 \\
& $(94.4)$ & $(84.0)$ & $(90.1)$ & $(79.2)$ & $(88.9)$ & $(93.3)$ & $(89.0)$ & $(88.1)$ \\
$\mathrm{T}_{10}$ & 5.00 & 2.00 & 5.74 & 2.21 & 0.72 & 1.35 & 4.20 & 1.18 \\
\hline
\end{tabular}

All values are the mean of 6 observational dates from 14 days to 49 days after transplanting.

Figures within parentheses are the percent reductions over control.

$\mathrm{ULS}=$ Upper leaf surface; LLS $=$ Lower leaf surface 
$\mathrm{T}_{1}=$ planting of musk melon as trap crop, $\mathrm{T}_{2}=$ hand picking of adult RPB, $\mathrm{T}_{3}=$ use of mosquito net barrier, $\mathrm{T}_{4}=$ Forwatap 4G @ $4 \mathrm{~g} /$ plant twice at 10 days interval, $\mathrm{T}_{5}=$ Forwatap 4G@3 g/plant twice at 10 days interval, $\mathrm{T}_{6}=$ Emithion 50 EC @ 2 ml/L of water twice at 7 days interval, $\mathrm{T}_{7}=$ Morter $48 \mathrm{EC} @ 1 \mathrm{ml} / \mathrm{L}$ of water twice at 7 days interval, $\mathrm{T}_{8}=$ Vitabryl $85 \mathrm{WP} @ 3.34 \mathrm{~g} / \mathrm{L}$ of water twice at 7 days interval, $\mathrm{T}_{9}=$ Nitro 505 EC @ $1 \mathrm{ml} / \mathrm{L}$ of water twice at 7 days interval and $\mathrm{T}_{10}=$ untreated control.

The findings of the present study may be concluded that the mechanical collection and destruction of the beetles from crop fields should, therefore, be done during study period. During the middle of the day when the outdoor temperature becomes hot due to intense sunlight, the adult RPB are found more on the lower surfaces of leaves than on the upper surfaces. As the adults are found on both surfaces of a leaf, both sides of the leaves of a food plant must be sprayed with a suitable contact insecticide with good residual action and low mammalian toxicity for the effective control of the adult beetles.

\section{REFERENCES}

Alam, M.Z. 1969. Pest of cucurbit vegetables. In: Insect-pests of vegetables and Their Control in East Pakistan. Agri. Infor. Serv., Dept. Agri., Dacca. pp. 87-110.

Annonymous. 1995. Annual Research Report (1994-95), Entomology Division, Bangladesh Agricultural Research Institute, Joydebpur, Gazipur. pp. 39-41.

Anonymous, 2007. Annual Research Report 2006-07, Entomology Division, BARI, Gazipur. pp. 60-61.

Atkins, M.D. 1978. Insects In Perspective. Macmillan Publishing Co. Inc. New York Collier Macmillar Publishers London. 513p.

Austin, G.D. 1925. Some beetle pests of cucurbits in Ceylon. Rev. Appl. Ent. Ser. A. 13: 358.

Azim, M.I.I. 1966. Studies on the biology of red pumpkin beetle, Aulacophora foveicollis (Lucas) (Chrysomelidae: Coleoptera) in East Pakistan. M. Sc. Thesis. Department of Entomology. Bangladesh Agricultural University, Mymensingh. pp. 1-95.

Borah, R. K. 1997. Effect of insecticides on pest incidence in cucumber (Cucumis sativus) in hill zone of Assam. Indian J. Agric. Sci. 67 (8): 332-333.

Bose, T.K. and Som, M.G. 1998. Vegetables Crops in India. 150p.

Butani, D.K. and Jotwani, M.G. 1984. Insects in Vegetables. Periodical Expert Book Agency. Vivek-Vihar, Delhi , India. pp. 356.

Chapman, R.F. 1979. The insects structure and function. Second edition. Published by Elsevier North Holland, Inc. 52 Vanderbilt Avenue, New york N. Y. 10017. 819p.

Chattopadhyay, P. 1991. Keetatatta, Keetadaman O Shasya Sanrakshan. West Bengal State Book Board, Arjo Mansion ( $9^{\text {th }}$ floor), 6A, Raja Subodh Mollick Square, Calcutta-70013, India. $2^{\text {nd }}$ Edition. 375p. (in Bangla).

Chauhan, D.B.S. 1989. Vegetable Production in India. Ram Prasad and Sons. Agra, Bhopal, India. $183 p$.

FAO (Food and Agricultural Organization). 2003. Inter country programme for integrated pest management in vegetables in South and South-East Asia. Eggplant integrated pest management: An ecological guide. 177p.

Hazarika, S.H. 1951. Red pumpkin beetle, Aulacophora foveicollis (Lucas) Fb. In: Destructive Insect of East Pakistan and Their Control. Dacca Publishers. Dacca 65p.

Hill, D.S. 1983. Agricultural Insect Pest of the Tropics and Their Control. $2^{\text {nd }}$ edition. Cambridge University Press, London. 40-41p. 
Krishnaiah, K., Jagan Mohan, N. and Prasad, V. G. 1979. Evaluation of insecticides for the control of major pests of musk melon. Indian J. Ent. 41: 311.315.

Nair, M.R.G.K. 1986. Insects and Mites of Crops in India. Publication and Information Division, Indian Council of Agricultural Research. New Delhi. pp. 162-169.

Rashid, M.M. 1993. Kumra Paribarer Shabji. In: Shabji Bijnan (in Bengali). Bangla Academy, Dhaka, Bangladesh. pp. 254-356.

Reddy, D.B. and Joshi, N.C. 1992. Plant Protection in India. Second ed. Allieed Publ. Ltd. New Delhi. 550p.

Singh, D., Narang, D. D. and Chahal, B. S. 1984. Control of red pumpkin beetle, Raphidopalpa foveicollis Lucas by foliar and soil application of insecticides. J. Res. PAU. 21 (4): 525532.

Yawalkar, K.S. 1985. Vegetable Crops of India. Agri-Horticultural Publishing House. Nagpur. India. 374pp. 